Plant Syst. Evol. 236: 207-220 (2003)

DOI $10.1007 / \mathrm{s} 00606-002-0233-\mathrm{x}$

\title{
A reassessment of tribal affinities of Cratystylis and Haegiela (Asteraceae) based on three chloroplast DNA sequences
}

\author{
R. J. Bayer and E. W. Cross \\ CSIRO, Plant Industry, Centre for Plant Biodiversity Research, Australian National Herbarium, \\ Canberra City, Australia
}

Received August 26, 2002; accepted September 19, 2002

Published online: February 7, 2003

(C) Springer-Verlag 2003

\begin{abstract}
The tribal affinities of Cratystylis and Haegiela were assessed using three chloroplast DNA sequences, the $\operatorname{tr} n \mathrm{~L} / \mathrm{F}$ spacer, the $\operatorname{tr} n \mathrm{~L}$ intron and the mat $\mathrm{K}$ coding region. The outgroup was represented by two species of the subfamily Barnadesioideae, whereas one to seven genera (45 species including Cratystylis and Haegiela) of the tribes of the Asteroideae [Anthemideae (6 genera), Astereae (7), Calenduleae (2), Gnaphalieae (7), Heliantheae s.l. (5), Inuleae s.str. (3), Plucheeae (3), Senecioneae (4)] and Cichorioideae, [Arctotideae (1), Cardueae (2), Lactuceae (2), Liabeae (1), Mutisieae (1) and Vernonieae (1)] comprise the ingroup. Phylogenetic analysis indicates that Cratystylis has strong support as a member of the tribe Plucheeae, whereas Haegiela is a member of Gnaphalieae. At some point in their taxonomic history, both genera have been placed in these tribes and there are good morphological and chemical characters that justify these placements. The monotypic Haegiela was once included in Epaltes (Plucheeae) and this study has confirmed the need for the separation of the two genera. The genus Cratystylis appears to be monophyletic.
\end{abstract}

Key words: Asteraceae, Cratystylis, Haegiela, Gnaphalieae, everlastings, molecular phylogeny, tribe, cpDNA, mat $\mathrm{K}$, $\operatorname{trn} \mathrm{L} / \mathrm{F}$ region.

Our continuing studies on the phylogeny and systematics of the tribe Gnaphalieae (Astera- ceae), have necessitated the reevaluation of the phylogenetic position of several Australian, South American, and South African genera. Recent treatments of the Gnaphalieae (Anderberg 1991a, Anderberg in Bremer 1994) have placed several enigmatic genera within this tribe, including Haegiela P.S. Short and Paul G. Wilson. On the other hand, while Cratystylis $\mathrm{S}$. Moore has been in a broad Inuleae (sensu Bentham 1873) it has never been placed directly in Gnaphalieae. Bremer (1994) treated Cratystylis as a member of the subfamily Cichorioideae, but did not assign it to a tribe. These genera have suites of morphological and chemical traits, which offer conflicting clues as to their tribal affinities. Currently there is no molecular study to assist in providing corroborating evidence to the compelling question of their tribal alliance.

Taxonomic history of Cratystylis. Cratystylis is a genus of four functionally dioecious, sometimes spiny, shrubs with linear to spathulate, usually grey/blue leaves that occur in southern Australia, from Western Australia to Victoria and far western New South Wales. The capitula are solitary, homogamous, epaleate, with chartaceous involucral bracts in six to eight rows. The florets are deeply lobed, the 
anthers caudate, and the style branches have very short hairs dorsally and extending immediately below the bifurcation. Cypselae are glabrous with a pappus of scabrid-barbellate bristles and a substantial and undivided carpopodium.

The taxonomic history of Cratystylis is long and convoluted. Eurybia (Cass.) Cass. was originally erected by Cassini as a section of Aster L. In 1855, Ferdinand von Mueller described Eurybia conocephala F. Muell. Later, Mueller (1865) transferred the taxon into Aster, as Aster conocephalus (F. Muell.) F. Muell., and he gave as a basionym and a synonym respectively, Eurybia conocephala and Olearia conocephala F. Muell. nomen nudum. Bentham (1867) validated Olearia conocephala (F. Muell.) Benth. in Flora Australiensis; despite what Mueller may have intended. Therefore, this taxon was now in a third genus of the Astereae. Bentham and Hooker (1873) retained the taxon as Olearia conocephala in Genera Plantarum, and Mueller (1887) transferred it into Pluchea Cass., thereby changing its tribal position to the Inuleae, subtribe Plucheineae. It is difficult to determine tribal placement in Die natürlichen Pflanzenfamilien (Hoffmann 1890-1894) because the epithet "conocephala" was not specifically mentioned under any of the four genera in which it had been placed.

Moore (1905) transferred Pluchea conocephala (F. Muell.) F. Muell. to a new genus Cratystylis, as Cratystylis conocephala (F. Muell.) S. Moore, which he placed in Inuleae. He also validated two nomina nuda of Mueller and Tate (1896), Pluchea conocephala var. microphylla and var. subspinescens, as additional species of Cratystylis, C. microphylla $\mathrm{S}$. Moore and $C$. subspinescens $\mathrm{S}$. Moore. This brought the total number of species in the genus to three. The superfluous generic name Stera Ewart was proposed in Ewart et al. (1911), and as they were apparently unaware of Moore's (1905) paper on Cratystylis, they published the three species Stera conocephala (F. Muell.) Ewart and B. Rees, S. microphylla Ewart and B. Rees and S. spinescens Ewart and B. Rees. Hutchinson (in Ostenfeld 1921) described Pteronia australiensis Hutch. (= Cratystylis conocephala), as Ostenfeld had given the specimen to Hutchinson because he could not identify it. Subsequently, Hutchinson placed it in a genus with which he was very familiar from South Africa, Pteronia L. He was excited about this finding because it could be used as evidence of a former land connection between Australia and South Africa. The resemblance of Pteronia to Cratystylis is, however, merely superficial. Placing Cratystylis conocephala in Pteronia also leads us to conclude that Hutchinson (in Ostenfeld 1921) considered Cratystylis as a member of the Astereae. Black (1929, 1957), in the 'Flora of South Australia', and Willis, in the 'A Handbook to Plants of Victoria' (1973), left Cratystylis in the Inuleae sensu Bentham (1873). In their tribal revision of the Inuleae, Merxmüller et al. (1977) place Cratystylis in the Inuleae: Inulinae, but admit that the taxon is unusual in a number of characteristics, including its subdioecious breeding system and the size and position of the stigmatic surface.

Zdero et al. (1988, 1991) investigated the phytochemical composition of Cratystylis in order to settle its tribal affinity. They determined that the secondary chemistry of both Cratystylis conocephala and C. microphylla were most similar to the Plucheoid Sphaeranthus L. and close to Epaltes Cass. and Pluchea Cass. These plants contain large amounts of $2 \alpha$-hydroxycostic acid and eudesmanolide (cratystyolide triacetate).

In 1989, Anderberg suggested that Cratystylis lacked the diagnostic features of the Plucheeae and that the genus would best be placed in another tribe. Later, Anderberg (1991b) pointed out that the placement of Cratystylis, as a member of the Pluchea group of the Inuleae (Plucheeae sensu Anderberg), was aberrant because of its unusual characteristics, both morphological and chemical. Anderberg et al. (1992) further stated that Cratystylis was a member of neither Plucheeae nor Inuleae (subfamily Asteroideae), but more closely allied to tribes in the subfamily 
Cichorioideae. They cited the 6-8 rows of phyllaries, the deeply lobed corolla, and style with minute hairs distributed below the bifurcation and stigmatic area as anomalous in Asteroideae. Detailed pollen studies revealed that Cratystylis has prominently spined, caveate, pollen grains, a thin foot layer, internal foramina and a complex 2-3 layered sexine. This differs from the Inuloid pollen type in that the pollen of Cratystylis possesses a double sexine and pronounced internal tectum and no singular baculate layer. This has also distinguished the pollen from many, but not all, Plucheeae, which have a single columellate sexine. Anderberg et al. (1992) did, however, note the similarity of Cratystylis pollen to that of Stenachaenium Benth. (Plucheeae). They concluded that the pollen type was like that of the Arctoteae (Cichorioideae), in spite of the rarity of caveate pollen in Cichorioideae and preponderance in Asteroideae. They additionally rejected the phytochemical assessment of Zdero et al. (1988) asserting that Cratystylis was more similar to the Cichorioid tribes, Arctotideae or Cardueae.

On the basis of a cladistic analysis of the morphology, Anderberg et al. (1992) concluded that Cratystylis is isolated within Cichorioideae and closely related to Vernonieae, Liabeae, and Lactuceae. Hunger (1997), in her revision of Australian Pluchea, accepted Anderberg's exclusion of Cratystylis from the Plucheeae/Inuleae. Lately, Wilson and Albrecht (2002) described a fourth species of Cratystylis, C. centralis Paul G. Wilson and Albr., and accepted Anderberg's placement of the genus as an isolated element in subfamily Cichorioideae.

Taxonomic History of Haegiela. Haegiela is a monotypic genus of annual herbs distributed in arid areas of southern Australia from New South Wales and Victoria west to Western Australia. Its leaves are small, basally opposite, sessile, ovate to lanceolate, and covered with a cobwebby indumentum. The capitula are small, axillary, heterogamous, epaleate and surrounded by 15 to 20 involucral bracts, the outer scarious and silvery translucent, the inner subcartilaginous. The florets are shallowly four-lobed, and papillose, the stamens strongly caudate, and the style branches are very short and truncate apically. The cypselae are minutely papillose, epappose, with a substantial and undivided carpopodium.

Haegiela tatei (F. Muell.) P.S. Short and Paul G. Wilson was originally described by Mueller (1883) as Epaltes tatei F. Muell., and for most of its taxonomic history it has resided in Epaltes. Epaltes (tribe Vernonieae sensu Cassini) was erected by Cassini in 1819 to accommodate Ethulia divaricata L., a clearly misplaced taxon. At the time of Lessing (1832), there were four species in Epaltes, which he placed in his subtribe Tarchonantheae (Tribe Asteroideae). Following Lessing, DeCandolle (1836) placed Epaltes in the subtribe Tarchonantheae (tribe Asteroideae), but recognized eight species. Both Lessing and de Candolle placed the subtribe Tarchonantheae near genera currently in the modern tribes Inuleae and Plucheeae. Bentham (1873) positioned Epaltes in the Inuleae, subtribe Plucheineae, and believed that the nine species of Epaltes formed a "very natural" group1. In 1883, Mueller described Epaltes tatei and stated that although he believed the taxon was somewhat anomalous in Epaltes, he did not have the conviction to transfer it to its own genus. The ten species of Epaltes remained a part of Inuleae: Plucheinae in Hoffmann's (18901894) monograph of the Compositae. Floristic works of South Australia (Black 1929, 1957) and Victoria (Willis 1973) placed Epaltes in the Inuleae.

Leins (1971), in his study of the systematic utility of pollen grain morphology in Asteraceae, was the first to strongly suggest that Epaltes tatei did not fit in Epaltes, nor in the subtribe Plucheinae. His conclusion was based both on the morphology of pollen grains, as

\footnotetext{
1 "The genus [Epaltes] as a whole is a very natural one, although the species of each region have been raised into separate genera upon characters which scarcely deserve more than specific rank."
} 
well as that of the capitula (Leins 1971). He also maintained that $E$. tate $i$ was very similar to Stuartina, of the Gnaphaliinae ${ }^{2}$. Skvarla et al. (1977), in evaluating pollen morphology, placed Epaltes tatei in subtribe Inulinae (Inuleae), and Merxmüller et al. (1977) suggested that all Epaltes species could be placed in the Pluchea group (Inuleae subtribe Inulinae). Anderberg (1989), accepting that Epaltes tatei was misplaced in the genus Epaltes, placed it in the Filago L. clade of his resurrected Gnaphalieae. Short and Wilson (1990) accepted Lein's suggestion ${ }^{3}$ that $E$. tatei be moved into a new genus (Leins 1971) and transferred E. tatei to a new genus Haegiela. Epaltes, now excluding Haegiela tatei, expanded in the 200 years following Cassini's first species into a genus of 14 currently recognized species (Anderberg in Bremer 1994).

In the present study, we use DNA sequence data in an attempt to elucidate the tribal relationships of Cratystylis and Haegiela. We selected the $\operatorname{trn} \mathrm{L} / \mathrm{F}$ spacer, the $\operatorname{trn} \mathrm{L}$ intron and the mat $\mathrm{K}$ coding region to resolve the phylogeny of the Asteraceae, as these regions have proven useful in resolving generic and tribal relationships in the Asteraceae (Bayer and Starr 1998, Bayer et al. 2002, Konishi et al. 2000).

\section{Materials and methods}

Source of material. Fieldwork was conducted in Australia. Fresh and/or herbarium material of Cratystylis conocephala, C. subspinescens, and

\footnotetext{
${ }^{2}$ Innerhalb der Gnaphaliinae kommt sic der australischen monotypischen Gattung Stuartina am nächsten, mit der sie unter anderem die niedrige Wuchsform, die zusammengedrängten, kleinen, heterogamen Köpfchen, die wenigen, trockenhäutigen, glänzenden Hüllschuppen und die pappuslosen Blüten gemeinsam hat. (Translated into English by Randall Bayer: "Within the Gnaphaliinae, the Australian monotypic genus Stuartina comes closest [to Epaltes tatei], considering, among the things, the low stature and the small, heterogamous heads, which have a few, dry-membranous, shining, outer phyllaries and epappose florets".)

${ }^{3}$ lch schlage deshalb vor, die als Epaltes tatei beschriebene Sippe in eine neue Gattung neben Stuartina zu stellen. (Translated into English by Randall Bayer: "I suggest, therefore, placing Epaltes tatei into a new genus beside Stuartina".)
}

Haegiela tate $i$ was utilized for the purpose of DNA extraction and morphological study (Table 1). Cratystylis conocephala and $H$. tatei both represent the types of their respective genera. Material of the other ingroup and outgroup taxa were either collected in the wild or obtained from commercial sources (Table 1).

Taxon selection. The matrix consists of two outgroup taxa (Barnadesioideae) and 45 ingroup members (Asteroideae and Cichorioideae) and three members of the two genera, Cratystylis and Haegiela, of incertae sedis. Voucher specimens for all taxa are deposited in the herbaria cited in Table 1. Outgroup taxa were selected in accordance with the well supported placement of the Barnadesioideae as the earliest diverging lineage in the Compositae (Jansen and Palmer 1987, Bremer 1987, Kim and Jansen 1995, Bayer and Starr 1998), and are represented by two Barnadesioids, Chuquiraga aurea Skottsb. and Doniophyton anomalum (D. Don) Wedd. One to seven genera (45 species) represent all of the tribes of the Asteroideae [Anthemideae (6 genera), Astereae (7), Calenduleae (2), Gnaphalieae (7), Heliantheae s.l. (5), Inuleae s.str. (3), Plucheeae (3), Senecioneae (4)] and Cichorioideae, [Arctotideae (1), Cardueae (2), Lactuceae (2), Liabeae (1), Mutisieae (1) and Vernonieae (1)] and comprise the ingroup (see Table 1). Tribal circumscriptions and nomenclature in this work are based on the treatment of the Asteraceae by Bremer (1994).

DNA Isolation, amplification, sequencing and alignment. Ten new sequences were generated for this study (Table 1, which includes GenBank accessions numbers). The remaining DNA sequences are taken from our previous studies (Bayer and Starr 1998, Bayer and Cross 2002). Total DNA was isolated as outlined in Bayer et al. (1996), and DNA amplification and sequencing are exactly as given in Bayer and Cross (2002). Likewise the alignment of sequences proceeded by hand following the principles discussed in Bayer and Cross (2002).

Sequence data analysis. Sequence data were analyzed using PAUP 4.0610 (Swofford 2001). Phylogenetic reconstruction was performed on unweighted characters by heuristic searches with 1000 replicates of random addition of taxa to search for further islands of most parsimonious trees (Maddison 1991). Two data sets were 
R. J. Bayer and E. W. Cross: Affinities of Cratystylis and Haegiela

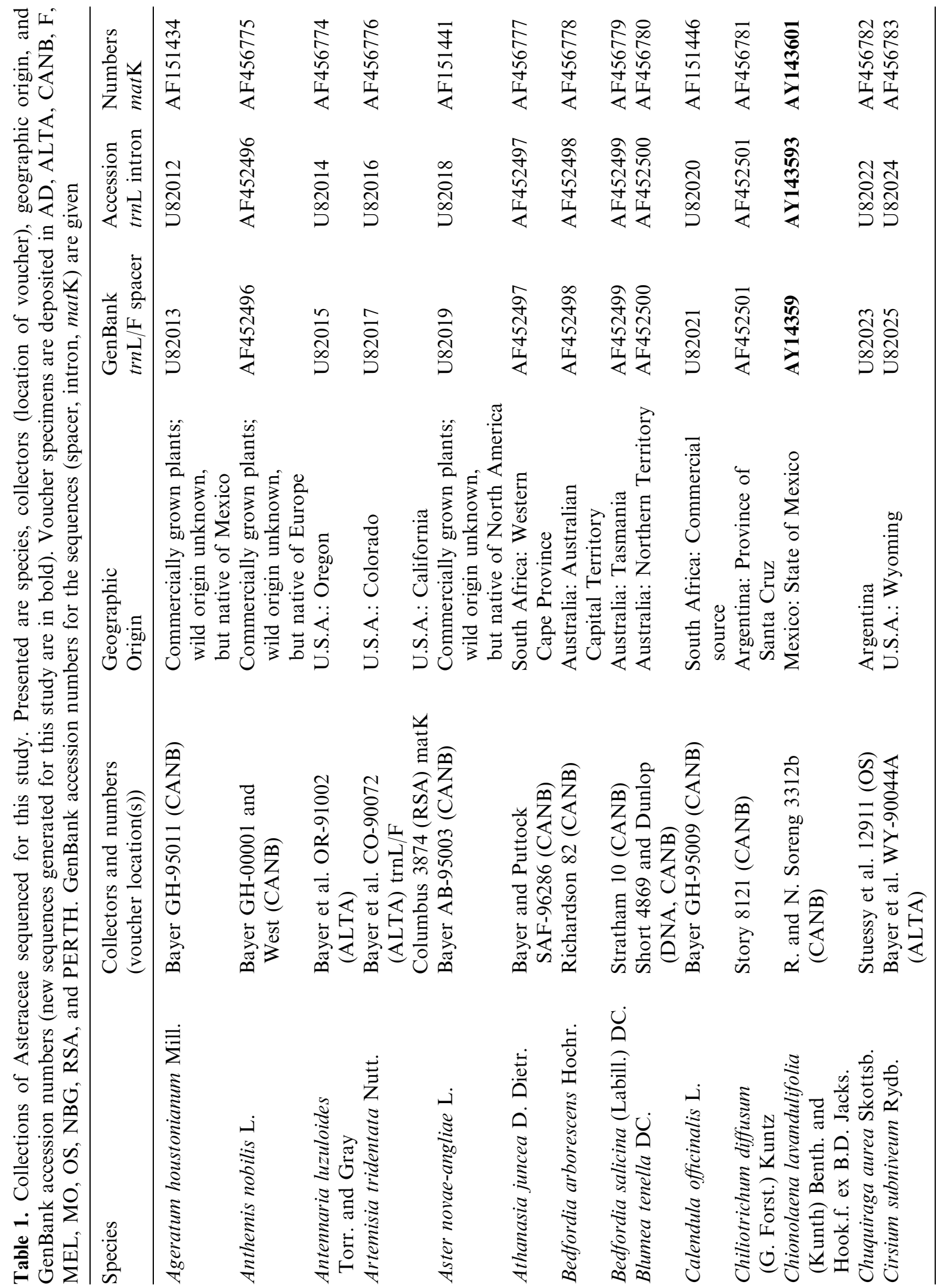




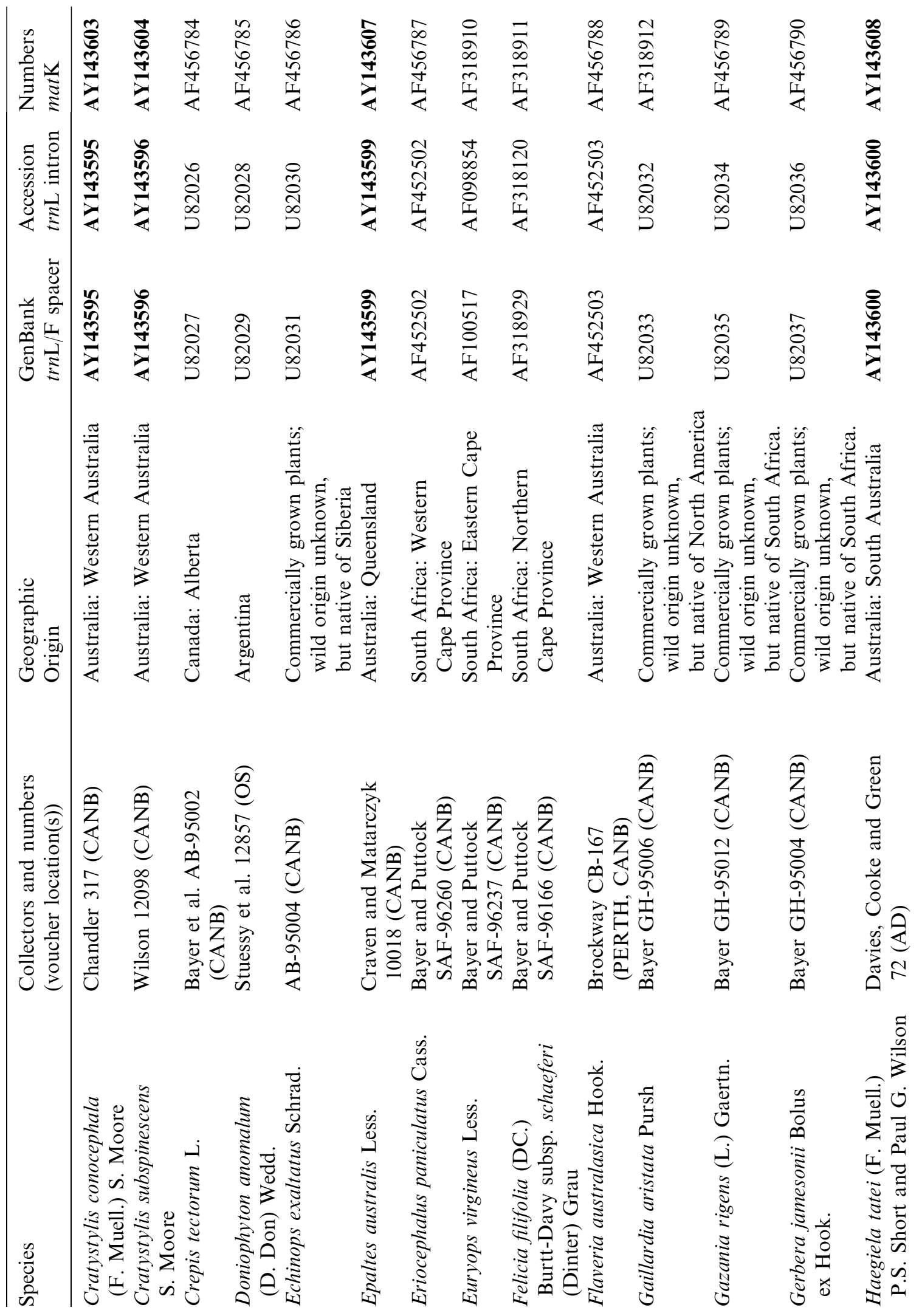




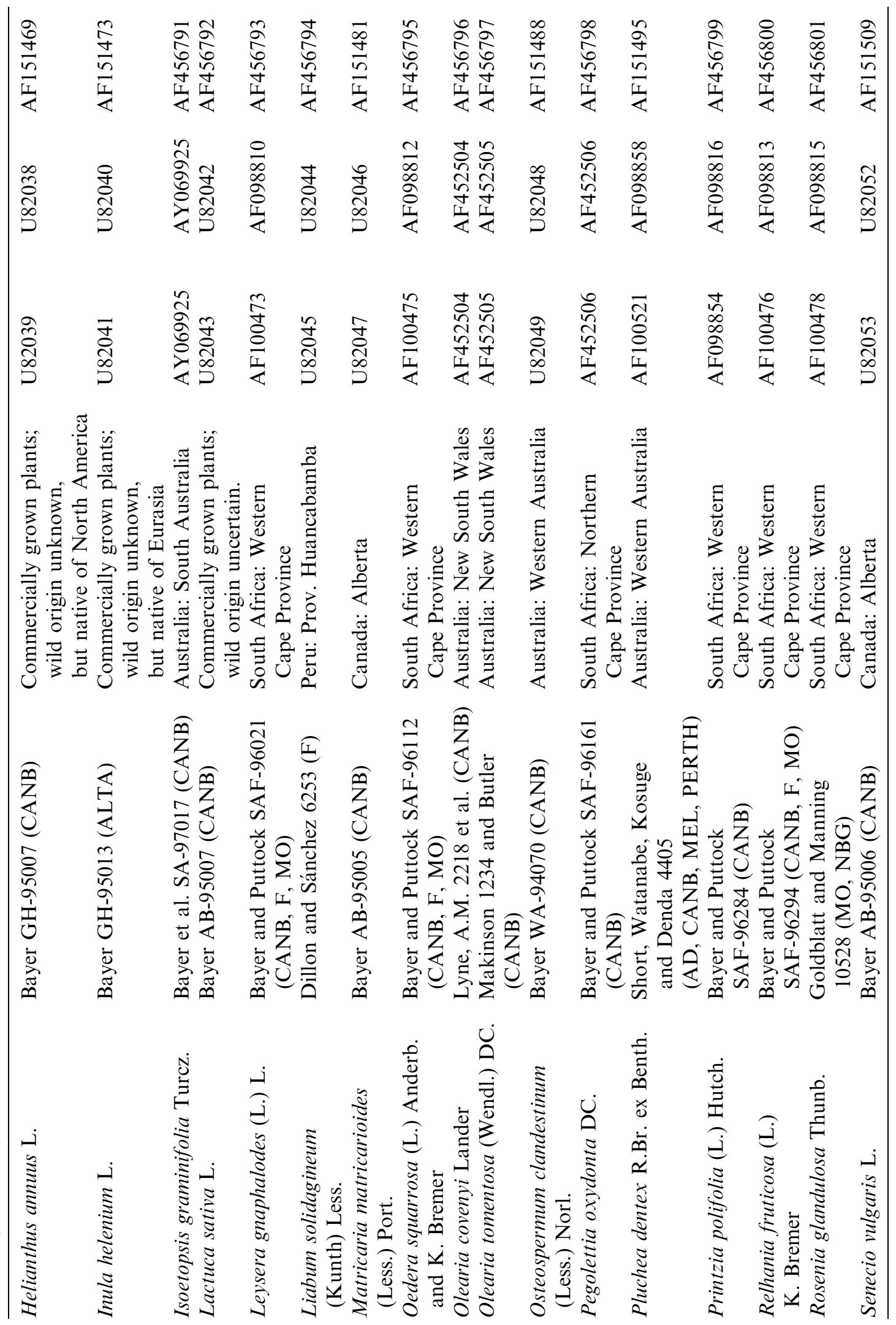




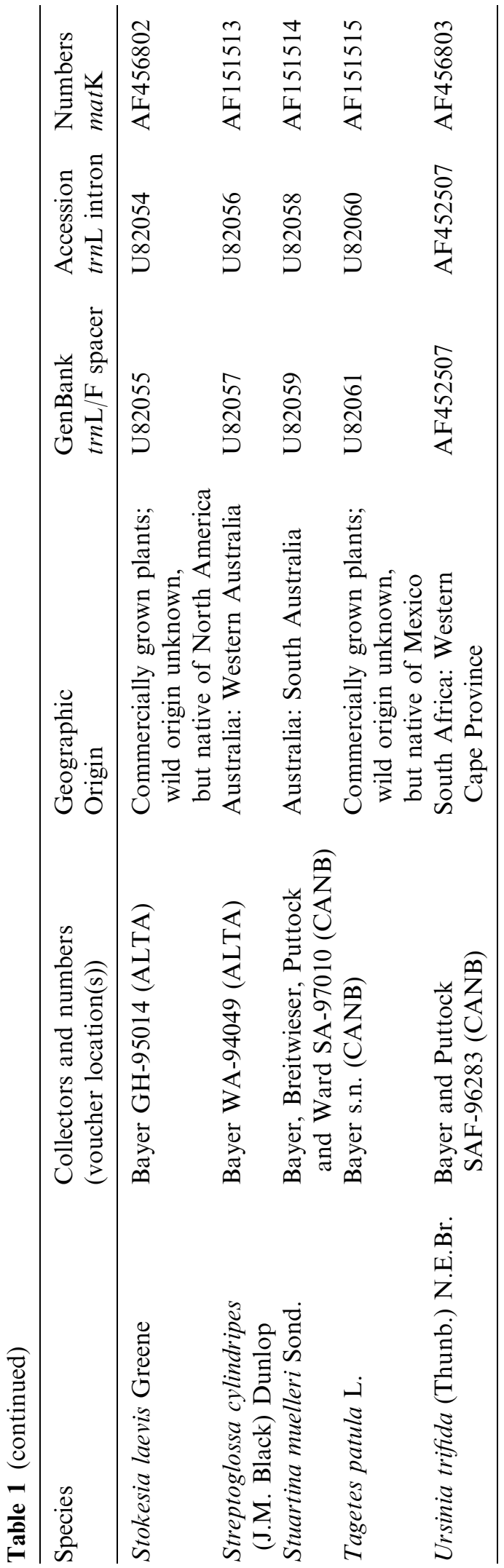

analysed; the first excluded all the coded indels, and the second included all indels and nucleotide characters. Forty-three coded indels were included in the final analysis, which improved resolution and strengthened support in the resulting trees. Indels were scored as binary characters for use in analyses, following the recommendations of Wojciechowski et al. (1993), van Ham et al. (1994) and Lloyd and Calder (1991) with gaps treated as missing data. The robustness of clades was assessed using a resampling protocol, jackknife analysis (Felsenstein 1988 ) with 10,000 replicates and $33 \%$ character deletion.

\section{Results}

Phylogenetic analysis yielded one island of 56 most parsimonious trees of length 1231 steps. The strict consensus of these trees (Fig. 1) and a phylogram (Fig. 2) detailing branch length, indicate that the Asteroideae is a strong monophyletic lineage (Figs. 1-2, synapomorphies $(\mathrm{SYN})=4$; jackknife value $(\mathrm{JKV})=$ $89 \%$ ). They are sister to an evolutionary grade of tribes from the Cichorioideae with the two outgroup taxa from the Barnadesioideae. Thus, we have found confirmation that the Cichorioideae is paraphyletic, as most other studies have reported (see Bayer and Starr, 1998 for a complete discussion of the Cichoriodieae paraphyly issue).

The following tribes, Astereae $(\mathrm{SYN}=8$; $\mathrm{JKV}=87 \%)$, Anthemideae $(\mathrm{SYN}=35 ; \mathrm{JKV}=$ $100 \%)$ Calenduleae $(\mathrm{SYN}=61 ; \quad \mathrm{JKV}=$ $100 \%)$, Gnaphalieae $(\mathrm{SYN}=8 ; \mathrm{JKV}=82 \%)$, Helianthieae s.l. $(\mathrm{SYN}=6 ; \quad \mathrm{JKV}=100 \%)$, Inuleae + Plucheeae $(S Y N=19 ; J K V=67 \%)$, Plucheeae $(\mathrm{SYN}=12 ; \mathrm{JKV}=96 \%)$; Lactuceae $(\mathrm{SYN}=11 ; \mathrm{JKV}=100 \%)$, and Senecioneae $(\mathrm{SYN}=40 ; \mathrm{JKV}=100 \%)$ have strong support for monophyly. On the whole, support for the tribes throughout the topologies is high (Figs. 1-2), with most branches being supported by multiple synapomorphies.

With respect to Cratystylis and Haegiela, both genera are placed in what were once tribes that were included in the Inuleae (Figs. 1-2). Two species of Cratystylis, $C$. conocephala and C. subspinescens, are sister taxa in Plucheeae 


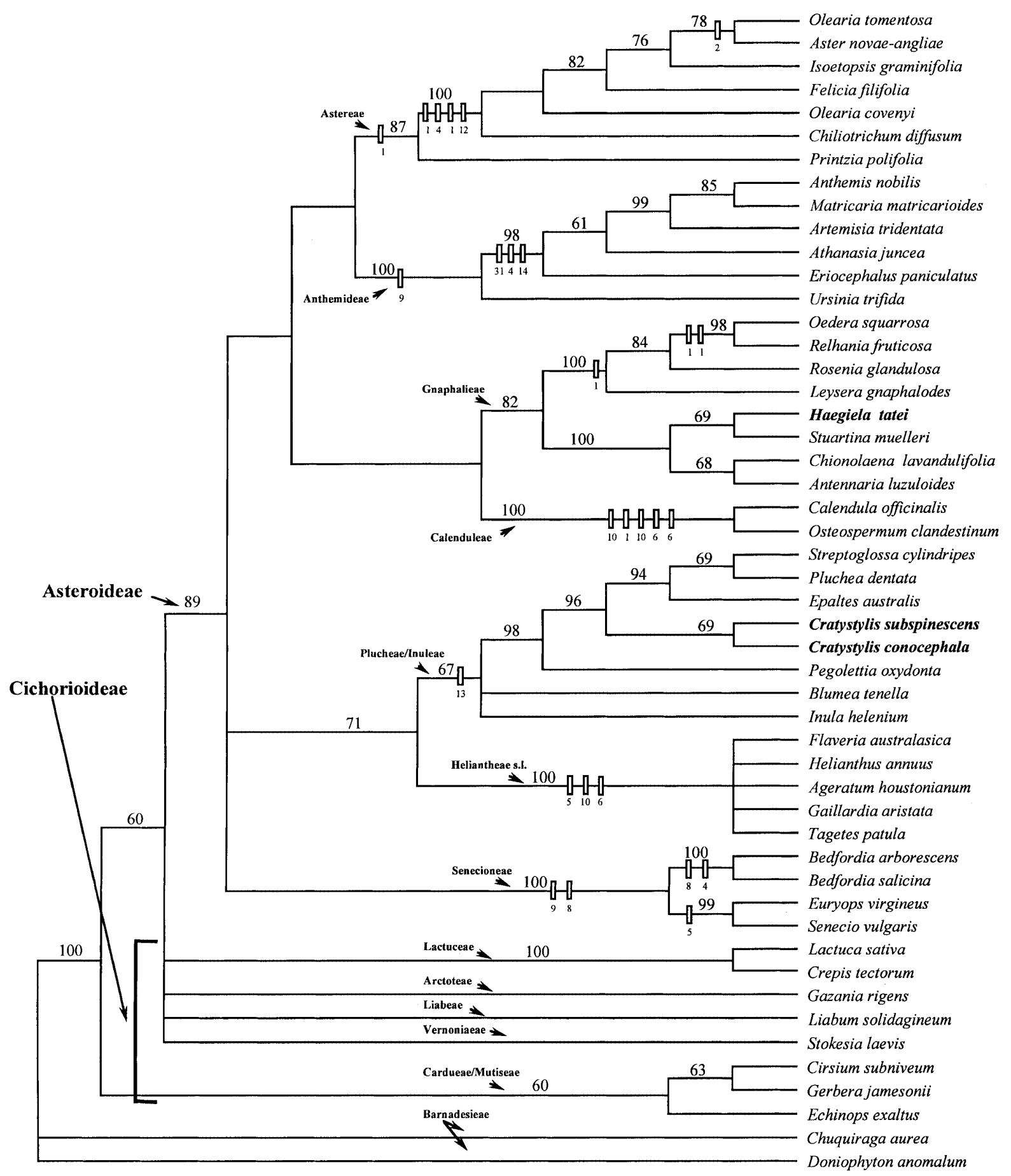

Fig. 1. Strict consensus of 56 trees of length 1231 in one island found from an heuristic search of the combined molecular data sets. $\mathrm{CI}=0.6954, \mathrm{RI}=0.7658, \mathrm{RCI}=0.5325$. Jackknife values $>50 \%$ are shown on the branches. Informative indels are mapped on the tree as broad bars. The length of the indels is indicated below the bars 


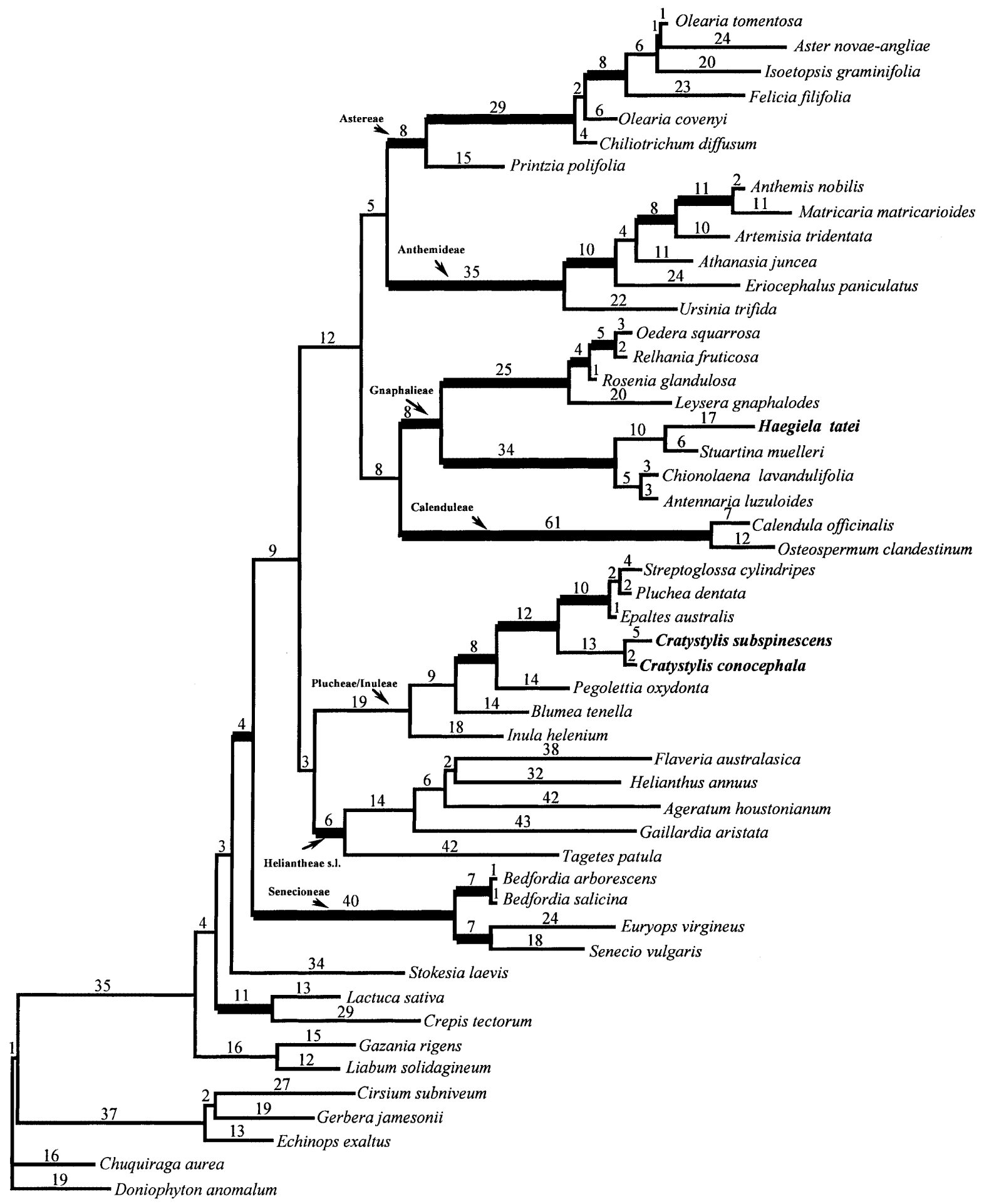

Fig. 2. A phylogram derived from one of the 56 most parsimonius trees. Branch lengths, and the numbers above the branches, are the number of changes. Bold branches receive $>80 \%$ jackknife support as in Fig. 2 
$(\mathrm{SYN}=12, \mathrm{JKV}=96 \%)$ and sister to the remaining species of Plucheeae. Haegiela is sister to Stuartina muelleri $\quad(\mathrm{SYN}=10$; $\mathrm{JKV}=69 \%)$ in the Gnaphalieae $(\mathrm{SYN}=8$; JKV of $82 \%$ ).

\section{Discussion}

Throughout their taxonomic histories, both Cratystylis and Haegiela have been placed variously within several tribes of the Asteraceae. Here we discuss their tribal placement based on the results of our molecular analysis and in light of morphology.

Cratystylis as a member of the Plucheeae. For the first 30 years of its history, Cratystylis was regarded as a member of the tribe Astereae based on its perceived resemblance to the large Australasian genus Olearia Moench. In 1887, when Mueller transferred the taxon to Pluchea, by implication, he transferred it to another tribe (Plucheeae). He noted that the narrow style branches and the sagittate anther tails allied the taxon to Pluchea rather than Olearia or Aster. Although somewhat anomalous in Pluchea, Mueller (1887) argued that the generic circumscription of Pluchea should be broadened to include Cratystylis. When Moore (1905) formally described Cratystylis as a separate genus, he remarked that he could "only marvel why" Bentham didn't place them in their own genus rather than retaining the three species in Olearia. He argued for a placement of Cratystylis in Inuleae (sensu Bentham 1873), because of the tailed anthers and thickened style branches. As Cratystylis differed from Pluchea in capitulum morphology, he rejected it being subsumed into an enlarged Pluchea. When Merxmüller et al. (1977) placed Cratystylis in the Pluchea group of their subtribe Inulinae, they claimed it was anomalous in being dioecious and having stigmatic rows that converge near the base and cover nearly the whole surface. Interestingly, there are some species of Pluchea (P. tetranthera F. Muell. and $P$. baccharoides (F. Muell.) Benth.) which are imperfectly dioecious (Mueller 1887).
Further, Zdero et al. (1988, 1991), present compelling chemical evidence for placement of Cratystylis in the Plucheeae, and this taken together with historical morphological data concurs with our placement of Cratystylis in a group of genera (Figs. 1 and 2), related to Pluchea. Additional carpopodial characters also support this placement; Haque and Godward (1984) surveyed carpopodia throughout the Asteraceae and found that members of subfamily Cichoriodieae had narrow carpopodia usually formed in sectors instead of complete rings, whereas Asteroideae usually have substantial carpopodia that form complete rings at the proximal end of the cypsela. Here we report that Cratystylis has the Asteroideae type of carpopodium, forming a complete and substantial ring.

In placing Cratystylis in Cichorioideae, close to Arctoteae, Anderberg et al. (1992) considered that both the morphological and palynological traits of Cratystylis were inconsistent with the traditional view of a Plucheoid/ Inuloid affinity; we find this conclusion untenable. The multiple rows of involucral bracts found in Cratystylis, though common in Barnadesioideae and Cichorioideae (Anderberg et al. 1992), do occur in many Asteroideae such as the Australian endemic Pluchea baccharoides which has 6-7 (8) rows of involucral bracts (Hunger 1997). Likewise, caveate pollen is almost exclusive to the Asteroideae and very rare in Cichorioideae (Bolick 1978). The external structure of the pollen with a double tectum between the spines is very similar to the Plucheoid Stenachaenium (Anderberg et al. 1992), while the pollen diameter/exine thickness ratio (Bolick 1991) fall within the expected ranges for members of the Asteroideae.

Given the position of Cratystylis in the molecular phylogeny, coupled with its morphological similarities to members of the Plucheeae, we see no reason why Cratystylis should not be reinstated in the tribe Plucheeae, as first proposed by Ferdinand von Mueller (1887) over one hundred years ago.

Haegiela as a distinct genus and a member of the Gnaphalieae. The molecular data robustly 
indicate that Haegiela is distinct from Epaltes and is a well supported member of the tribe Gnaphalieae. This concurs with Mueller (1883) who discussed the anomalous placement of Haegiela in Epaltes, Leins (1971) who considered the detailed palynology of both groups, and Short and Wilson (1990) who transferred Epaltes tatei into a new monotypic genus Haegiela. Haegiela shares many morphological features with Gnaphalieae including heterogamous discoid heads, epaleate involucre, the shortly caudate anthers, and truncate style branches with long sweeping stigmatic hairs.

Although the placement of Haegiela in Gnaphalieae is very robust, the generic relationships are difficult to ascertain given the limited sampling of only 7 species from within the tribe. Preliminary molecular data of both $m a t \mathrm{~K}$ and $\operatorname{trn} \mathrm{L} / \mathrm{F}$ sequences (unpubl. matrix) including a wide range of Australian genera (see Bayer et al. 2002), shows that Haegiela is in a clade that it is topologically distant from Stuartina, and belongs to the same major clade as both Waitzia and Triptilodiscus. This is broadly concordant with the treatments of both Wilson (1992) and Anderberg (1991a). The molecular data (see Figs. 1 and 2), also support the placement of Epaltes in Plucheae, as suggested by Bentham (1873). It is clear, however, that further representatives of Epaltes are required to substantiate this claim.

In recent molecular and morphological studies (Anderberg 1991c, Eldenas et al. 1999), the Plucheeae remains a strong monophyletic lineage. Our recent molecular findings (Bayer and Starr 1998, Bayer et al. 2000, Bayer et al. 2002, Bayer and Cross, 2002) support a strong monophyletic Gnaphalieae that is topologically distant from the Inuleae/Plucheeae clades in all molecular phylogenies. The morphological similarities of Haegiela to other members of the Gnaphalieae and its location in the molecular phylogeny suggests that Haegiela should remain in the Gnaphalieae. This was first implied by Leins
(1971) when he studied the pollen morphology of the species.

In summary, there is now ample molecular and morphological evidence to establish the tribal position of Cratystylis in the tribe Plucheeae and Haegiela in Gnaphalieae.

We thank Greg Chandler (VCU) and Lyn Craven (CANB) for supplying leaf material of Cratystylis conocephala and Epaltes australis, respectively. We are also grateful to Neil H. Bagnall for assistance in the lab. The authors thank Laurie Adams for assistance in interpretation of some Latin, and Greg Chandler, Mark Clements, Robert Godfree, Pauline Ladiges, and Brendan Lepschi for suggested improvements to our manuscript. This research was supported by a National Geographic Grant to R.J.B.

\section{References}

Anderberg A. A. (1989) Phylogeny and reclassification of the tribe Inuleae (Asteraceae). Canad. J. Bot. 67: 2277-2296.

Anderberg A. A. (1991a) Taxonomy and phylogeny of the tribe Gnaphalieae (Asteraceae). Opera Bot. 104: 1-195.

Anderberg A. A. (1991b) Taxonomy and phylogeny of the tribe Inuleae (Asteraceae). Plant Syst. Evol. 176: 75-123.

Anderberg A. A. (1991c) Taxonomy and phylogeny of the tribe Plucheeae (Asteraceae). Plant Syst. Evol. 176: 145-177.

Anderberg A. A., Karis P. O., El-Ghazaly G. (1992) Cratystylis, an isolated genus of the Asteraceae Cichorioideae. Austral. Syst. Bot. 5: 81-94.

Bayer R. J., Soltis D. E., Soltis P. S. (1996) Phylogenetic inferences in Antennaria (Asteraceae: Inuleae: Gnaphaliinae) based on sequences from the nuclear ribosomal DNA internal transcribed spacers (ITS). Amer. J. Bot. 83: 516-527.

Bayer R. J., Starr J. R. (1998) Tribal phylogeny of the Asteraceae based on two non-coding chloroplast sequences, the $\operatorname{trn} \mathrm{L}$ intron and $\operatorname{trn} \mathrm{L} / \operatorname{trn} \mathrm{F}$ intergenic spacer. Ann. Missouri Bot. Gard. 85: 242-256.

Bayer R. J., Puttock C. F., Kelchner S. A. (2000) Phylogeny of South African Gnaphalieae (Asteraceae) based on two non-coding chloroplast sequences. Amer. J. Bot. 87: 259-272. 
Bayer R. J., Greber D. G., Bagnall N. H. (2002) Phylogeny of Australian Gnaphalieae (Asteraceae) based on four sequences, four sequences, the $\operatorname{trn} \mathrm{L}$ intron, $\operatorname{trn} \mathrm{L} / \operatorname{trn} \mathrm{F}$ intergenic spacer, matK, and ETS. Syst. Bot. (in press).

Bayer R. J., Cross E. W. (2002) A reassessment of tribal affinities of the enigmatic genera Printzia and Isoetopsis (Asteraceae), based on three chloroplast sequences. Austral. J. Bot. (in press).

Bentham G. (1867) Tribe VIII. Gnaphalieae. In Flora australiensis III. Lovell Reeve and Co., London, pp. 556-657.

Bentham G. (1873) Notes on the classification, history, and geographical distribution of Compositae. J. Proc. Linn. Soc. Bot. 13: 335-557.

Bentham G., Hooker J. D. (1873) Genera plantarum II. Lovell Reeve and Co., London.

Black J. M. (1929) Flora of South Australia, Edn. 1. Harrison Weir, Government Printer, Adelaide.

Black J. M. (1957) Flora of South Australia, Edn. 2. W. L. Hawes, Government Printer, Adelaide.

Bolick M. (1978) Taxonomic, evolutionary, and functional considerations of Compositae pollen ultrastructure and sculpture. Plant Syst. Evol. 130: 209-218.

Bolick M. (1991) Pollen diameter, exine thickness, and ultrastructure type in the tribes of the Compositae. Compositae Newslett. 19: 17-21.

Bremer K. (1987) Tribal interrelationships of the Asteraceae. Cladistics 3: 210-253.

Bremer K. (1994) Asteraceae: Cladistics and classification. Timber Press, Portland, Oregon.

Candolle A. P. de (1836) Prodr. V. Treuttel and Würtz, Paris.

Cassini H., (1819) Dict. Sci. Nat. 15: 6-8. Le Normant, Paris.

Eldenas P., Källersjö M., Anderberg A. A. (1999) Phylogenetic placement and circumscription of tribes Inuleae s. str. and Plucheeae (Asteraceae): Evidence from sequences of chloroplast gene $n d h$ F. Mol. Phyl. Evol. 13: 50-58.

Ewart A. J., White J., Rees B., Wood B. (1911) Contributions to the Flora of Australia, No 18. Proc. Roy. Soc. Victoria. 23(2): 255-268.

Felsenstein J. (1988) Phylogenies from molecular sequences: inference and reliability. Ann. Rev. Genet. 22: 521-565.

Haque M. Z., Godward M. B. E. (1984) New records of the carpopodium in Compositae and its taxonomic use. Bot. J. Linn. Soc. 89: 321-340.
Hoffmann O. (1890-1894) Compositae. In: Die natürlichen pflanzen-familien, Teil: IV, 5: 87391. Wilhelm Engelmann Publ., Leipzig.

Hunger S. (1997) A survey of the genus Pluchea (Compositae, Plucheeae) in Australia. Willdenowia 27: 207-223.

Jansen R. K., Palmer J. D. (1987) A chloroplast DNA inversion marks an ancient evolutionary split in the sunflower family (Asteraceae). Proc. Natl. Acad. Sci., USA. 84: 1-5.

Kim K-J., Jansen R. K. (1995) $n d h \mathrm{~F}$ sequence evolution and the major clades in the sunflower family. Proc. Natl. Acad. Sci. USA. 92: 1037910383.

Konishi N., Watanabe K., Kosuge K. (2000) Molecular systematics of Australian Podolepis (Asteraceae: Gnaphalieae): Evidence from DNA sequences of the nuclear ITS region and the chloroplast matK gene. Austral. Syst. Bot. 13: 709-727.

Leins P. (1971) Pollensystematische Studien an Inuleen I. Tarchonanthinae, Plucheinae, Inulinae, Buphthalminae. Bot. Jahr. Syst. 91: 91-146.

Lessing C. F. (1832) Syn. Gen. Compos. Duncker and Humblot, Berlin.

Lloyd D. G., Calder V. L. (1991) Multi-residue gaps, a class of molecular characters with exceptional reliability for phylogenetic analysis. J. Evol. Biol. 4: 9-21.

Maddison D. R. (1991) The discovery and importance of multiple islands of most parsimonious trees. Syst. Zool. 40: 315-328.

Merxmüller H., Leins P., Roessler H. (1977) Inuleae-systematic review. In: Heywood V. H., Harborne J. B., Turner B. L. (eds.) The biology and chemistry of the Compositae 1. Academic Press, London, pp. 577-602.

Moore S. L. (1905) Alabastra diversa - Part XII. J. Bot. 43: 137-150.

Mueller F. J. H. (1855) Description of fifty new Australian plants, chiefly from the colony of Victoria. Trans. and Proc. Victorian Inst. Advancem. Sci. 1854-1855: 28-48.

Mueller F. J. H. (1865) Fragm. XXXV, 5: 75-102.

Mueller F. J. H. (1883) Diagnoses of a new genus and two species of Compositae from South Australia. Trans and Proc. Rep. Roy. Soc. South Australia 6: 31-33.

Mueller F. J. H. (1887) Remarks on Victorian Haloragis, and on the occurrence of the genus 
Pluchea within the Victorian territory. Bot. Centralbl. 32: 147-151.

Mueller F. J. H., Tate R. (1896) Botany. (Phanerogams and vascular cryptogams). Trans. and Proc. Roy. Soc. South Australia 16: 333-385.

Ostenfeld C. H. (1921) Contributions to Western Australian botany 3. Biol. Meddel. Kongel. Danske Vidensk. Selsk. 3(2): 1-144.

Short P. S., Wilson P. G. (1990) Haegiela, a new genus of Australian Asteraceae (Inuleae: Gnaphaliinae), with notes on the genus Epaltes Cass. Muelleria 7: 259-265.

Skvarla J. J., Turner B. L., Patel V. C., Tomb A. S. (1977) Pollen morphology in the Compositae and in morphologically related families. In: Heywood V. H., Harborne J. B., Turner B. L. (eds.) The biology and chemistry of the Compositae 1. Academic Press, London, pp. 141-229.

Swofford D. (2001) PAUP*: Phylogenetic analysis using parsimony, pre-release version 4.0b4a. Laboratory of Molecular Systematics, Smithsonian Institution and Sinauer Press, Washington D.C. and Sunderland, Massachusetts, respectively.

van Ham R. C. H., t' Hart J. H., Mes T. H. M., Sandbrink J. M. (1994) Molecular evolution of noncoding regions of the chloroplast genome in the Crassulaceae and related species. Curr. Genet. 25: 558-566.

Willis J. H. (1973) A handbook to plants in Victoria II. Melbourne University Press, Carlton.
Wilson P. G. (1992) The classification of Australian species currently included in Helipterum and related genera (Asteraceae: Gnaphalieae): part 1. Nuytsia 8: 379-438.

Wilson P. G., Albrecht D. E. (2002) Notes on the genus Cratystylis (Asteraceae), including one new species. Nuytsia 14: 445-452.

Wojciechowski M. F., Sanderson M. J., Baldwin B. G., Donoghue M., (1993) Monophyly of the aneuploid Astragalus (Fabaceae): evidence from the nuclear ribosomal DNA internal transcribed spacer sequences. Amer. J. Bot. 80: 711-722.

Zdero C., Bohlmann F., Haegi L., King R. M. (1988) Eudesmanolides and other constituents from Cratystylis conocephala. Phytochemistry 27: 865-868.

Zdero C., Bohlmann F., Anderberg A., King R. M. (1991) Eremophilane derivatives and other constituents from Haeckeria species and further Australian Inuleae. Phytochemistry 30: 26432650 .

Address of the authors: Randall J. Bayer (e-mail: Randy.Bayer@csiro.au), Edward W. Cross (e-mail: Ed.Cross@csiro.au), CSIRO, Plant Industry, Centre for Plant Biodiversity Research, Australian National Herbarium, GPO Box 1600, Canberra City, 2601, Australia. 